\title{
Purification of an embryotrophic factor from commercial bovine serum albumin and its identification as citrate
}

\author{
C. W. Gray*, P. M. Morgan and M. T. Kane† \\ Department of Physiology, University College, Galway, Ireland
}

\begin{abstract}
Summary. A factor of low $M_{\mathrm{r}}$ with growth-promoting effects on rabbit embryos was extracted and purified from commercial bovine serum albumin (BSA). This embryotrophic factor was extracted from BSA dissolved in formic acid by membrane filtration (membrane cutoff of $M_{\mathrm{r}} 10000$ ) and then freeze-drying of the filtrate. The extract was purified successively by chromatography on G-10 Sephadex, QAESephadex A-25 anion exchange and high-performance liquid chromatography (HPLC) reverse-phase columns. Mass spectrometry of the active reverse-phase material indicated that the major component in this material had an $M_{\mathrm{r}}$ of 192. The embryotrophic factor in the low $M_{\mathrm{r}}$ extract of BSA was shown to be citrate, because: (i) the mass spectra of the active reverse-phase material and citrate were identical, (ii) the activity was eluted at the identical position to citrate on an analytical HPLC anion-exchange column, (iii) the original BSA sample was shown by enzyme assay to be heavily contaminated by citrate and (iv) citrate stimulated cell proliferation and expansion of blastocysts.
\end{abstract}

Key'tords: blastocyst; citrate; albumin; rabbit

\section{Introduction}

Mice and rabbits are the only animals for which there is detailed information on the nutritional requirements for preimplantation embryo culture. The two species show markedly different requirements, which are related to their differing growth patterns. Mouse blastocysts at the end of the preimplantation period have $\approx 100$ cells (Bowman \& McLaren, 1970) and $20 \mathrm{ng}$ of protein slightly less than at the one-cell stage (Brinster, 1967). In striking contrast, rabbit blastocysts at implantation have $\approx 80000$ cells (Daniel, 1964) and $\approx 200 \mu \mathrm{g}$ of protein $-\approx 10000$ times that in mice (Lutwak-Mann, 1971). One-cell mouse embryos can be cultured to blastocyst stages in a simple saline solution supplemented with a macromolecule and a suitable energy source, but without amino acids, vitamins or trace elements (Whitten \& Biggers, 1968). Cleavage of rabbit embryos from one-cell to morula can take place in a similar medium, but blastocyst formation requires amino acids (Kane \& Foote, 1970), and blastocyst growth and expansion require the presence of vitamins (Kane, 1988). Even with these additions, growth of rabbit blastocysts in vitro in the best available media is much more limited than growth in vivo (Fischer, 1987; Kane, 1987a), indicating that these media are still far from optimal and may lack essential growth factors.

Most embryo-culture media contain either serum or serum albumin (reviews by Brackett, 1981; Kane, 1987a). The presence of albumin appears to be necessary for growth of rabbit blastocysts (Kane \& Headon, 1980), but there are considerable differences between different batches of albumin in embryotrophic properties (Kane, 1983), which may be due, in part at least, to the

\footnotetext{
*Present address: MRC Collaborative Centre, National Institute of Medical Research, Mill Hill, London NW7 IAD, UK.

†o whom reprint requests should be addressed.
} 
presence of contaminants. We have shown previously that it is possible to extract a fraction of low $M_{\mathrm{r}}$ from some samples of commercial bovine serum albumin (BSA) which markedly stimulates cell division of rabbit morulae cultured to blastocysts and increases blastocyst expansion (Kane, 1985). The present study reports the chromatographic purification of this embryotrophic factor and its identification as citrate.

\section{Materials and Methods}

\section{Preparation of Amicon extract of BSA of low $M_{r}$}

The BSA used was the same lot number of Fraction V BSA used previously (Kane, 1985), i.e. lot no. 120F-0089 (cat. no. A 4503; Sigma, Poole, Dorset, BH17 NH, UK); $50 \mathrm{~g}$ at a time was dissolved in $2.5 \%$ formic acid and filtered through a hollow-fibre cartridge (cat. no. HP 10 20, Amicon, Stonehouse, Gloucester, UK) with a cutoff of $10 \mathrm{kDa}$. The filtrate was collected and freeze-dried. The average yield of freeze-dried filtrate was $0.65 \mathrm{~g} / 50 \mathrm{~g}$ of BSA.

\section{Chromatographic purification of embryotrophic factor from extract of low $M_{\mathrm{r}}$}

The Amicon extract of low $M_{\mathrm{r}}$ was fractionated by a series of chromatographic columns (gel-filtration, anion-exchange and reverse-phase) for purification of the factor responsible for embryotrophic activity (for details of chromatographic columns, see Results section).

\section{Assay of embryotrophic activity}

The composition of the basic culture medium to which additions were made for all experiments was $0.25 \%$ charcoal-treated (defatted) bovine serum albumin, $\mathrm{NaCl}(108 \mathrm{mmol} / 1), \mathrm{KCl}(4 \cdot 78 \mathrm{mmol} / \mathrm{l}), \mathrm{CaCl}_{2} \cdot 2 \mathrm{H}_{2} \mathrm{O}$ (I.71 mmol/l), $\mathrm{KH}_{2} \mathrm{PO}_{4}(1.19 \mathrm{mmol} / \mathrm{l}), \mathrm{MgSO}_{4} \cdot 7 \mathrm{H}_{2} \mathrm{O}(1 \cdot 19 \mathrm{mmol} / \mathrm{l}), \mathrm{NaHCO}_{3}(25 \mathrm{mmol} / \mathrm{l})$, sodium pyruvate $(0.5 \mathrm{mmol} / 1)$ glucose $(1 \mathrm{mmol} / \mathrm{l})$ and the amino acids, vitamins and trace elements of Ham's FI0 medium (Ham, 1963; Kane \& Foote, 1970). The charcoal-treated BSA was included in the basic medium as BSA from which contaminants of low $M_{\mathrm{r}}$ had been removed by the charcoal treatment; it had negligible embryotrophic activity. In the experiment on the effects of citrate, additional pyruvate was added after 2 and 4 days of culture $(0.5 \mathrm{mmol}$ pyruvate $/ \mathrm{l}$ each time). All chromatographic separations were carried out using volatile buffers which were removed by freeze-drying from pooled peak fractions before assay for embryotrophic activity.

Embryos at the early morula stage were collected from the oviducts of superovulated New Zealand White does 44-48 h after injection with human chorionic gonadotrophin and insemination (Kane, 1987a). Embryos were placed in culture in $0.5-\mathrm{ml}$ droplets of culture medium under paraffin liquid (Art. 7174, Merck, Darmstadt, Germany) in tissue culture dishes or in $1 \mathrm{ml}$ medium covered by paraffin liquid in the wells of 24 -well tissue culture plates. In all experiments at the end of 5 days of culture, the numbers of blastocysts were recorded and blastocyst diameters measured with an eyepiece micrometer. In one experiment (assay of peaks from the G-10 gel-filtration column), blastocysts were stained with aceto-orcein-HCl (Grayson, 1978; Kane, 1983) and numbers of cells were counted under high power with the aid of an eyepiece micrometer grid. In another experiment (examination of the effect of citrate), blastocysts were labelled with $\left[{ }^{3} \mathrm{H}\right]$ thymidine for $4 \mathrm{~h}(5 \mu \mathrm{Ci} / \mathrm{ml})$ as an index of cell proliferation. The embryos were then washed free of culture medium, precipitated with $1 \mathrm{ml}$ of $10 \%$ trichloroacetic acid containing $5 \mu \mathrm{g}$ calf thymus DNA and stored frozen overnight. After thawing, the embryo samples were collected on glass microfibre filters (GFC, $2.5 \mathrm{~cm}$ diameter; Whatman, Maidstone, Kent, UK) and the acid-soluble material was washed through with $15 \mathrm{ml}$ of $10 \%$ trichloroacetic acid, followed by $5 \mathrm{ml}$ ethanol. The filters were placed in scintillation vials with $5 \mathrm{ml}$ scintillation cocktail (Ready Value; Beckman, High Wycombe, Bucks, UK) and radioactivity was measured in a scintillation counter for $10 \mathrm{~min}$.

Dunnett's procedure (Steel \& Torie, 1960) was used to compare statistically the effects of individual treatments with the control treatment (basic medium without additions).

\section{Examination of the effects of citrate}

The effect of citrate on development of morulae to expanded blastocysts was examined at different concentrations of citrate $(0,62 \cdot 5,125,250,500$ and $1000 \mu \mathrm{mol} / \mathrm{l})$.

\section{Mass spectrometry of reverse-phase material}

The active peak material from the reverse-phase preparative column was submitted to mass spectrometry. Fastatom-bombardment (FAB) spectra were obtained on a caesium-ion gun operating at $20 \mathrm{kV}$. The sample was dissolved 
in thioglycerol (Fluka AG, CH-9470, Buchs, Switzerland) matrix on the FAB probe tip and spectral data were acquired over a range of $1 \cdot 0-0.04 \mathrm{kDa}$ at a scan rate of $4 \mathrm{~s} /$ decade. Positive and negative ion spectra were recorded, the latter in multichannel analysis mode for increased sensitivity.

\section{Enzyme assay of citrate in BSA samples}

A number of commercial BSA samples and certain active chromatographic peaks were assayed for citrate concentration as described by Lowry \& Passonneau (1972).

\section{Results}

\section{Chromatography of the extract of low $M_{\mathrm{r}}$}

A G-10 Sephadex column was chosen for the first purification step, as data in our laboratory indicated that the material possessing embryotrophic activity passed through a molecular filter of $M_{\mathrm{r}} 500$. Freeze-dried extract was dissolved in $2.5 \%$ formic acid $(100 \mathrm{mg} / 5 \mathrm{ml})$ and chromatographed on a G-10 Sephadex gel-filtration column (fractionation range $M_{\mathrm{r}} 0-700$ ). The resulting elution profile showed three major peaks (Fig. 1a). Table 1 shows the effects of freeze-dried material from each of these three peaks on cell division and blastocyst expansion of rabbit morulae cultured to blastocysts. All the embryotrophic activity is present in peak 3 .

An anion-exchange column, QAE-Sephadex A-25, was chosen for the next purification step after preliminary trials indicated that the embryotrophic activity remained bound to the anion exchanger down to a $\mathrm{pH}$ of $\sim 2 \cdot 8$. Peak 3 material from the G-10 Sephadex column was dissolved $(100 \mathrm{mg} / \mathrm{ml})$ in $0.01 \mathrm{~mol}$ formic acid $/ 1(0.046 \%)$ and chromatographed on a QAE A-25 column using a gradient of $0.01-1.00 \mathrm{~mol}$ formic acid/1 (Fig. 1b). Fractions under each peak were pooled as indicated to give three major peaks and assayed for embryotrophic activity (Table 2). Both peak 2 and peak 3 promoted blastocyst expansion whereas peak 1 which was a composite of a number of peaks had no effect. Although two active fractions (QAE peaks 2 and 3) were recovered from QAESephadex A-25, their subsequent identical chromatographic behaviour indicated that the active material was present as just one compound (Gray, 1989). It is possible that nonspecific interactions with the Sephadex matrix were responsible for the separation into two fractions. The need for high concentrations of acid to elute the active peaks shows that the active compound is strongly acidic.

A reverse-phase column, the MinoRPC S 5/20 column (Pharmacia, Milton Keynes, UK), which separates molecules on the basis of their hydrophobicity was used next. Peak 3 material from the QAE A-25 column was dissolved $(500 \mu \mathrm{g} / 50 \mu \mathrm{l})$ in $0.1 \%$ trifluoroacetic acid (TFA) in water and applied to the MinoRPC column. The elution profile was monitored at $214 \mathrm{~mm}$ in this and all other HPLC separations because of the necessity to detect all peaks and because ultraviolet scans of the active QAE peaks 2 and 3 showed low ultraviolet absorbance above $220 \mathrm{~nm}$. The elution profile displayed two peaks not present in a blank run (Fig. Ic). Both peaks that were eluted with $0 \cdot 1 \%$ aqueous TFA before the acetonitrile gradient were assayed for embryotrophic activity (Table 3 ). The embryotrophic activity was present in peak 2 . The result indicates that the embryotrophic activity is too polar to interact with the reverse phase and possesses little if any hydrophobic character. A preparative reverse-phase Spherisorb C18 (Anachem, Luton, Beds, UK) column with a bed volume of $\approx 20 \mathrm{ml}$ was used to prepare large quantities of active material. Some of this material was subjected to mass spectrometry.

QAE peak 3 active material did not bind to an HPLC cation-exchange Mono S HR 5/5 column (Pharmacia) even at $\mathrm{pH} 2$, indicating an absence of positively charged groups, but it did bind to a hydroxyapatite HA Ultrogel column, indicating the presence of either phosphate or carboxyl groups (Gray, 1989). Based on this information, we used a Mono Q HR5/5 HPLC anion-exchange column (Pharmacia) in combination with an $\mathrm{HCl}$ gradient elution system (modified from Mayr, 1988) to compare the elution behaviour of the embryotrophic activity with a number of polyphosphate (AMP and ADP) and polycarboxylic compounds (EDTA, isocitrate and citrate). 

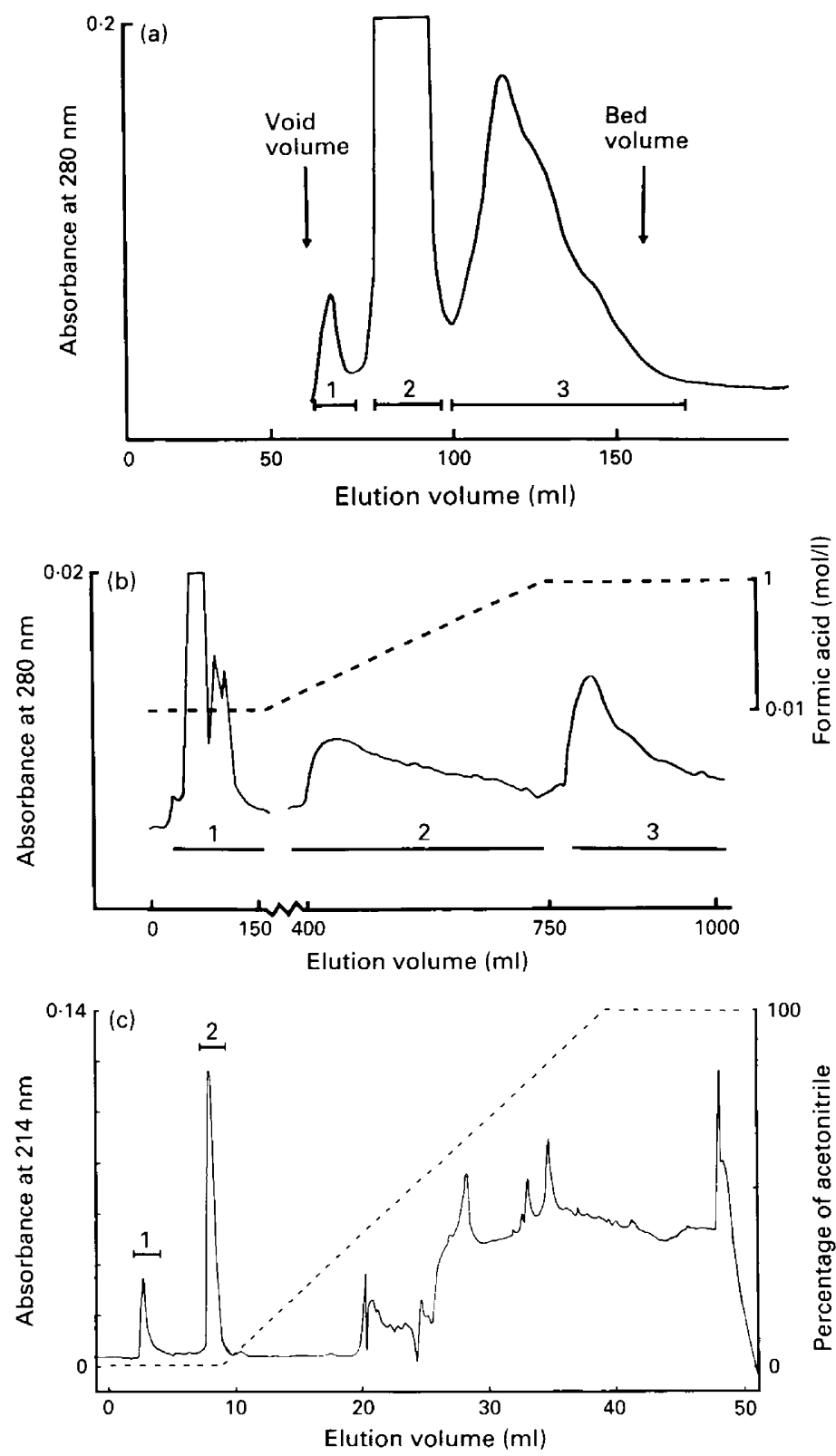

Fig. 1. Chromatographic purification of the embryotrophic factor of low $M_{\mathrm{r}}$ from bovine serum albumin (BSA). (a) Separation of low- $M_{\mathrm{r}}$ acid extract of BSA on a G-10 Sephadex gelpermeation column (diameter $1.6 \mathrm{~cm}$, height $77 \mathrm{~cm}$, bed volume $155 \mathrm{ml}$ ). The column was eluted with $2 \cdot 5 \%$ formic acid and the effluent monitored at $280 \mathrm{~nm}$. (b) Separation of peak 3 material from the G-10 column on a QAE-A 25 anion-exchange column (diameter $2.5 \mathrm{~cm}$, height $20.3 \mathrm{~cm}$, bed volume $100 \mathrm{ml}$ ). The column was eluted with $250 \mathrm{ml} 0.01 \mathrm{~mol}$ formic acid/1 followed by a $500-\mathrm{ml}$ gradient of $0.01-1.00 \mathrm{~mol}$ formic acid/l and then $250 \mathrm{ml} 1.0 \mathrm{~mol}$ formic acid/l. The effluent was monitored at $280 \mathrm{~nm}$. (c) Separation of peak 3 material from the QAE A-25 column on an HPLC MinoRPC S 5/20 reverse-phase column (diameter, $5 \mathrm{~mm}$, height $20 \mathrm{~cm}$, bed volume $3.3 \mathrm{ml}$ ). The column was eluted with $9 \mathrm{ml} 0.1 \%$ trifluoroacetic acid in water followed by a $30-\mathrm{ml}$ gradient of $0-100 \%$ acetonitrile (-- ) containing $0 \cdot 1 \%$ trifluoroacetic acid. The effluent was monitored at $214 \mathrm{~nm}$. 

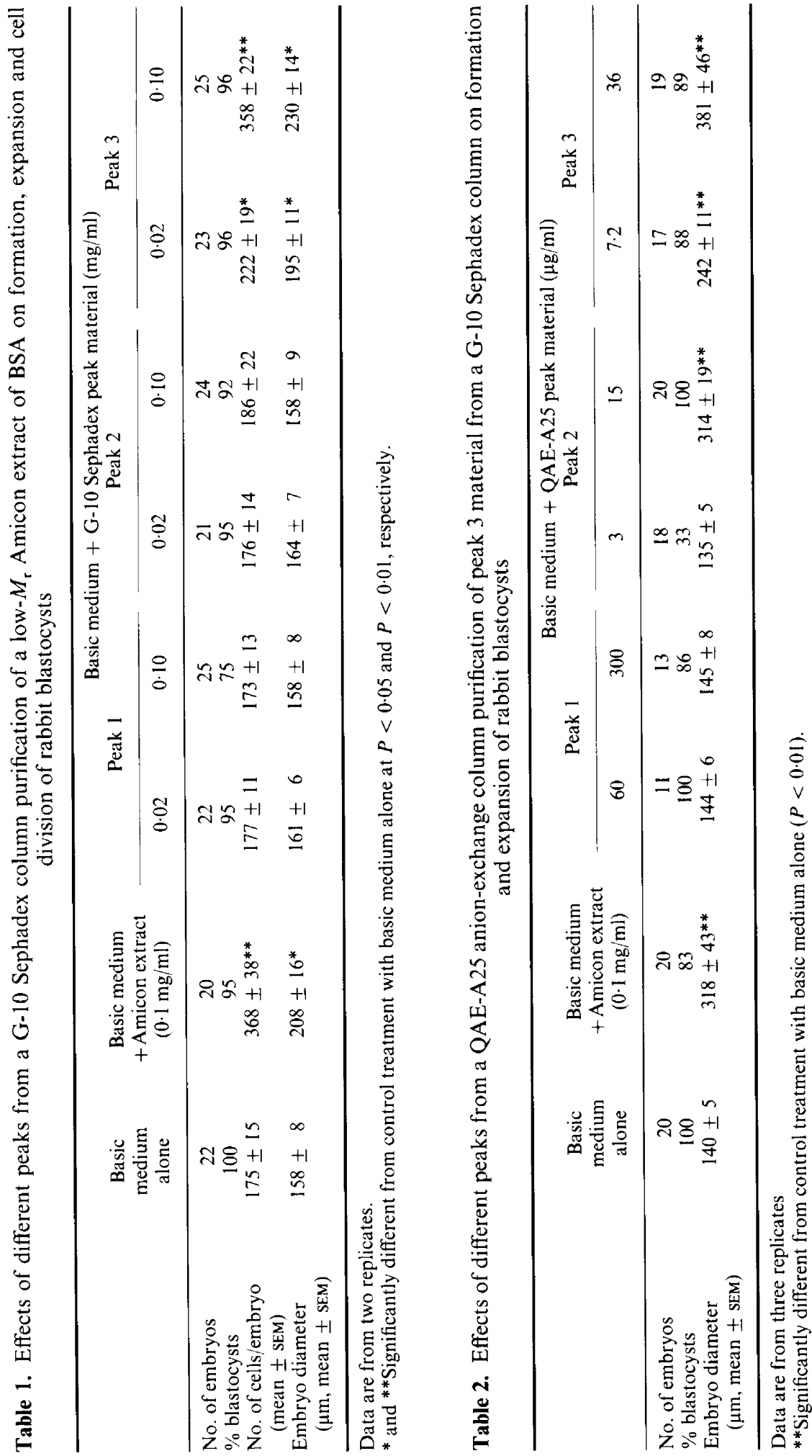
Table 3. Effects of different peaks from a reverse-phase Mino-RPC column for high-performance liquid chromatography on formation and expansion of rabbit blastocysts

\begin{tabular}{|c|c|c|c|c|c|}
\hline & \multirow{3}{*}{$\begin{array}{l}\text { Basic } \\
\text { medium } \\
\text { alone }\end{array}$} & \multicolumn{4}{|c|}{$\begin{array}{l}\text { Basic medium }+ \\
\text { Mino-RPC peak material }(\mathrm{mg} / \mathrm{ml})\end{array}$} \\
\hline & & \multicolumn{2}{|c|}{ Peak 1} & \multicolumn{2}{|c|}{ Peak 2} \\
\hline & & 20 & 100 & 20 & 100 \\
\hline No. of embryos & 48 & 6 & 6 & 8 & 44 \\
\hline$\%$ blastocysts & 92 & 100 & 100 & 100 & 100 \\
\hline $\begin{array}{l}\text { Embryo diameter } \\
\quad(\mu \mathrm{m}, \text { mean } \pm \mathrm{SEM})\end{array}$ & $130 \pm 2$ & $145 \pm 4$ & $150 \pm 15$ & $156 \pm 11$ & $264 \pm 27^{* *}$ \\
\hline
\end{tabular}

The data for basic medium alone and peak 2 at $100 \mathrm{mg} / \mathrm{ml}$ are from five replicates, all others are from one replicate.

${ }^{* *}$ Significantly different from control treatment with basic medium alone $(P<0 \cdot 01)$.

Active QAE peak 3 material, dissolved $(250 \mu \mathrm{g} / 500 \mu \mathrm{l})$ in $0.2 \mathrm{mmol} \mathrm{HCl} / 1$ in water was applied to a Mono Q column. The elution profile (Fig. 2) from the Mono Q column showed one peak not present in the blank (Mono $Q$ peak 3), which eluted at $6.58 \mathrm{mmol} \mathrm{HCl} / 1$. The embryotrophic activity was present in this peak (Table 4). Two phosphate compounds, AMP and ADP, eluted at 6.2 and $9.7 \mathrm{mmol} \mathrm{HCl} / 1$, respectively. The tetracarboxylic compound EDTA eluted at $15.2 \mathrm{mmol} / 1$ and the tricarboxylic compound isocitrate at $5.95 \mathrm{mmol} / 1$. Citrate, which was chosen fortuitously as another example of a tricarboxylic compound, eluted at $6.58 \mathrm{mmol} \mathrm{HCl} / 1$, the same position as the embryotrophic factor. Simultaneous application of citrate and embryotrophic QAE peak 3 material to the column resulted in their co-elution. This provided the first evidence that the embryotrophic factor of low $M_{\mathrm{r}}$ and citrate were identical.

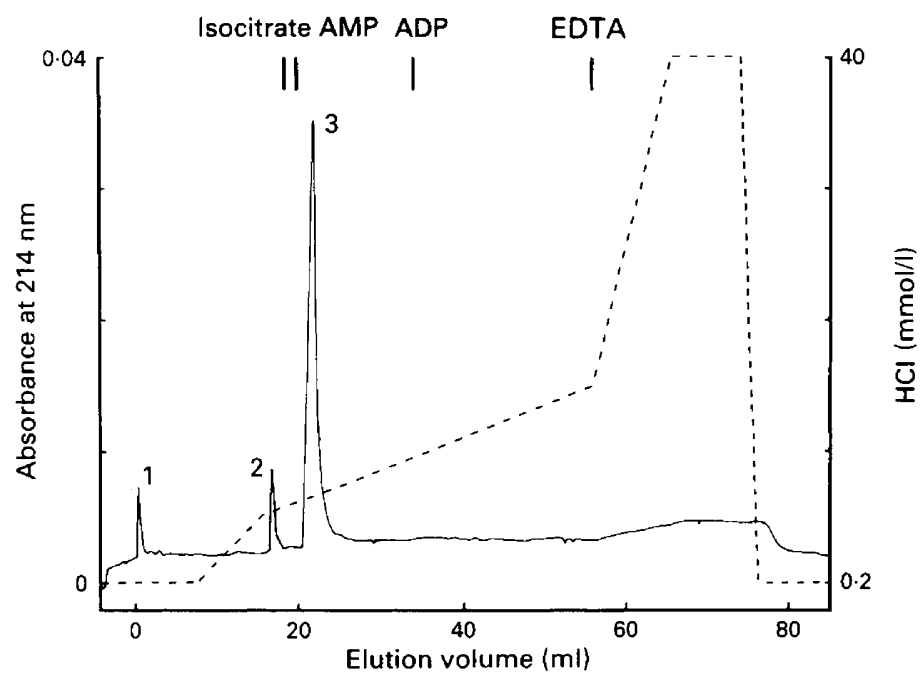

Fig. 2. Chromatographic separation of peak 3 material from a QAE A-25 column on an HPLC Mono Q 5/5 anion-exchange column (diameter $5 \mathrm{~mm}$, height $5 \mathrm{~cm}$, bed volume $1 \mathrm{ml}$ ). The column was eluted at $2.5 \mathrm{ml} / \mathrm{min}$ with $8 \mathrm{ml} 0.2 \mathrm{mmol} \mathrm{HCl} / \mathrm{l}$ followed successively by a $10 \mathrm{ml}$ gradient of $0.2-5 \mathrm{mmol} \mathrm{HCl} / \mathrm{l}$, a $40 \mathrm{ml}$ gradient of $5-15 \mathrm{mmol} \mathrm{HCl} / 1$ and a $10 \mathrm{ml}$ gradient of $15-40 \mathrm{mmol} / 1(---)$. The effluent was monitored at $214 \mathrm{~nm}$. The only peak not present in the blank was peak 3 . Citrate eluted at the same position as peak 3 . 
Table 4. Effects of a single peak from an anionexchange Mono Q column for high-performance liquid chromatography on rabbit blastocyst formation and expansion

\begin{tabular}{lcc}
\hline & $\begin{array}{c}\text { Basic } \\
\text { medium }\end{array}$ & $\begin{array}{c}\text { Basic medium + } \\
\text { Mono Q peak 3 } \\
(20 \mathrm{mg} / \mathrm{ml})\end{array}$ \\
\hline $\begin{array}{l}\text { No. of embryos } \\
\text { \% blastocysts }\end{array}$ & 24 & 25 \\
$\begin{array}{l}\text { Embryo diameter } \\
(\mu \mathrm{m}, \text { mean } \pm \text { SEM })\end{array}$ & $134 \pm 4$ & $205 \pm 100$ \\
\hline $\begin{array}{l}\text { Data are from five replicates. } \\
\text { *Significantly different from control treatment with basic } \\
\text { medium alone }(P<0.05) .\end{array}$
\end{tabular}

\section{Mass spectrometry of reverse-phase-purified material}

The FAB spectra of the embryotrophic material purified by G-10, QAE A-25 and Spherisorb chromatography clearly indicated an $M_{\mathrm{r}}$ of 192 as evidenced by the formation of $[\mathrm{M}-\mathrm{H}]^{+}$at 193 in positive ion mode and $[\mathrm{M}-\mathrm{H}]^{-}$in negative ion mode. Other peaks that could be readily assigned were $[\mathrm{M}-\mathrm{OH}]^{+}$at 175 and $[\mathrm{M}-\mathrm{COOH}]^{+}$at 147 , indicating the presence of hydroxyl and carboxyl groups. The $M_{\mathrm{r}}$ of citrate is 192 and FAB positive-ion spectrometry of citrate showed it to have an identical spectrum to the embryotrophic material. This provided further evidence for the identification of the embryotrophic factor as citrate.

\section{Citrate content of various BSA batches and fractions from extract of low $\boldsymbol{M}_{\mathrm{r}}$}

The citrate content of two lots of BSA from Sigma with previously documented embryotrophic activity on rabbit blastocysts (lots 41F-9300 (Kane, 1983) and 120F-0089 (Kane, 1985)), which were used for extraction of embryotrophic factor in the present work, was 2.44 and $8.08 \mu \mathrm{g} / \mathrm{mg}$ BSA, respectively. In contrast, a batch of BSA with negligible embryotrophic activity had $0.207 \mu \mathrm{g}$ citrate/mg BSA, and three batches of charcoal-treated BSA with no embryotrophic activity had undetectable citrate concentrations in two cases and $0.092 \mu \mathrm{g}$ citrate $/ \mathrm{mg}$ BSA in another case. Analysis of the QAE A-25 peaks 2 and 3 indicated that these peaks were $100 \%$ citrate by weight.

\section{Effects of citrate on expansion and cell proliferation of rabbit blastocysts}

There was a clear-cut effect of citrate in stimulating blastocyst growth, as shown by blastocyst expansion and uptake of $\left[{ }^{3} \mathrm{H}\right]$ thymidine into acid-precipitable material (Fig. 3). The optimal concentration of citrate was $0.5 \mathrm{mmol} / 1$. Embryos cultured in $0.5 \mathrm{mmol}$ citrate $/ 1$ grew to a mean blastocyst diameter of $357 \mu \mathrm{m}$ and incorporated $1406 \mathrm{c.p.m}$./embryo of $\left[{ }^{3} \mathrm{H}\right]$ thymidine, compared with a mean diameter of $144 \mu \mathrm{m}$ and $72 \mathrm{c.p.m}$./embryo for the control without citrate. Morulae cultured in the absence of citrate grew to the blastocyst stage, but after about 2-3 days in culture shrank down to their original unexpanded diameter.

\section{Discussion}

The identification of the formic-acid-extractable factor of low $M_{\mathrm{r}}$ associated with commercial samples of BSA as citrate rests on four compelling lines of evidence. The embryotrophic activity coeluted with citrate on the HPLC Mono Q system. Mass spectrometry of chromatographically pure material showed the same $M_{\mathrm{r}}$ and the same mass-spectrometric profile as citrate. Enzymatic assay 


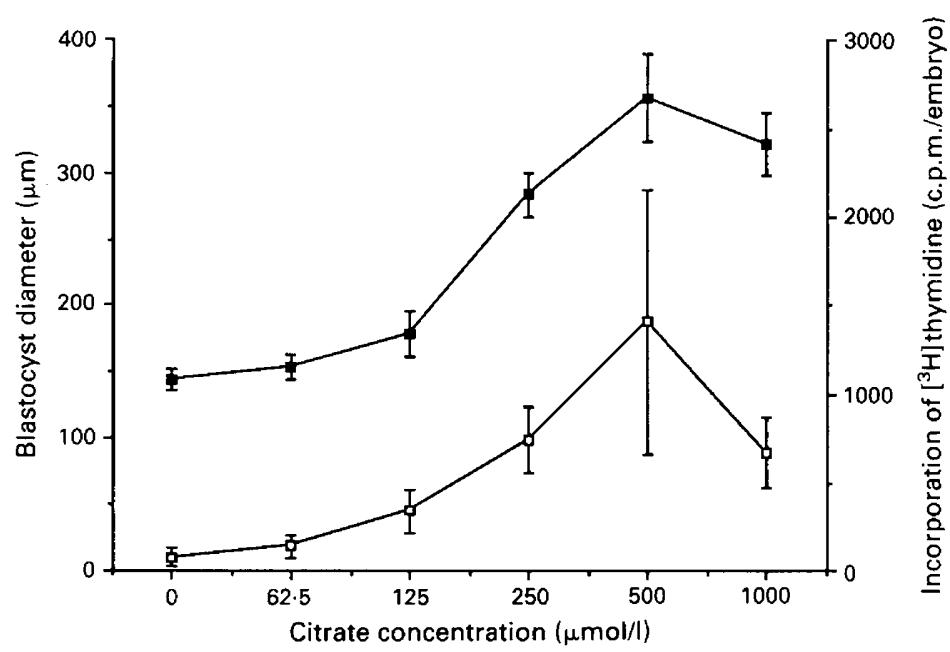

Fig. 3. Effects of citrate on expansion (diameter, $\mathbf{\square})$ and incorporation of $\left[{ }^{3} \mathrm{H}\right]$ thymidine $(\square)$ by rabbit blastocysts cultured from morulae. Plotted values are means \pm SEM based on four replicates and $22-26$ embryos per treatment.

showed that the original BSA was heavily contaminated with citrate and that the chromatographically pure factor was $100 \%$ citrate by weight. Citrate had an effect in stimulating growth of rabbit embryos similar to the active chromatographic fractions.

Citrate has long been known as a contaminant of commercial albumin preparations. Frye $e t$ al. (1974) reported $4.24 \mathrm{~mol}$ citrate $/ \mathrm{mol}$ albumin $(11.8 \mu \mathrm{g} / \mathrm{mg})$ in one sample. Possible sources of citrate include the normal concentrations of citrate in blood and, where plasma is used as a source of albumin, the citrate used to prevent clotting.

Citrate concentrations have been measured in freshly collected mouse embryos (Barbehenn et al., 1974). Citrate concentration is constant from the two-cell to the morula stage at $\approx 1.6 \mathrm{mmol} /$ $\mathrm{kg}$ wet weight. Individual citrate concentrations at the blastocyst stage were up to 12 times those at earlier stages, with a major portion of the citrate present in the blastocoel. An increasing amount of fixed carbon is found in both malate and citrate as development of the rabbit embryo progresses (Quinn \& Wales, 1974).

Previous data on the effects of citrate on preimplantation embryo development are limited. Brinster (1965) found that citrate did not support cleavage of two-cell embryos. However, citrate, in the absence of any other carbon sources, did support the development of eight-cell mouse embryos to the blastocyst stage (Brinster \& Thomson, 1966). Daniel (1967) found that citrate had a limited ability to act as the sole energy source for growth of rabbit blastocysts. It is unlikely that the growth stimulation by citrate revealed in our experiments is due to its action as an energy source, as the medium contains a wide range of potential energy sources, such as glucose, pyruvate and amino acids, which the rabbit embryo may use (Kane, 1987b).

There are a number of possible ways in which citrate might stimulate growth of rabbit blastocysts. The rate of fatty acid synthesis is greatly stimulated by citrate or isocitrate. Citrate is an allosteric activator of acetyl-CoA carboxylase and thus plays a key role in the control of fatty acid synthesis (Goodridge, 1972; Goodridge, 1973). Citrate promotes activity of acetyl-CoA carboxylase by inducing $30-40$ monomers of inactive enzyme to assemble into a fully active polymer.

The ability of citrate to chelate metal ions is well known: it has a high affinity for such cations as $\mathrm{Ca}^{2+}, \mathrm{Sr}^{2+}, \mathrm{Mn}^{2+}, \mathrm{Mg}^{2+}$ and $\mathrm{Fe}^{3+}$ (Cheberek \& Martell, 1959). It has been suggested that citrate, acting as a $\mathrm{Ca}^{2+}$ chelator, may open tight junctions in an epithelium, thereby enhancing the paracellular shunt pathway of solute transport (Cho et al., 1989). Concentrations of citrate as low as $0.1 \mathrm{mmol} / 1$ can chelate the $\mathrm{Ca}^{2+}$ required for maintaining junctional integrity. Thus citrate could 
be involved in promoting transport of $\mathrm{Ca}^{2+}$ or $\mathrm{Fe}^{3+}$ into rabbit blastocysts. There is good evidence that chelating agents such as EDTA stimulate development of mouse embryos (Abramczuk et al., 1977; Chatot et al., 1989; Toyoda et al., 1989).

The effect of citrate is clearly significant, if not essential, in promoting growth of rabbit blastocysts. However, addition of citrate does not improve the medium to the extent of reproducing full in vivo growth of blastocysts in vitro. We do not wish to suggest that the growth-promoting effect of commercial BSA preparations on preimplantation embryos is solely due to its citrate content, even for rabbit embryos. We are showing the effect of citrate in the presence of charcoal-treated BSA and we have not been able to replace the charcoal-treated BSA by a synthetic polymer such as polyvinylalcohol. In the presence of polyvinylalcohol as the only macromolecule in the medium, with or without citrate, a limited degree of blastocyst growth takes place. This may be due to the use of inappropriate concentrations of citrate or to the presence of other growth factors or functions associated specifically with albumin. The possibility that even charcoal-treated BSA may contain other growth factors is suggested by the fact that we have found (C. W. Gray, P. M. Morgan \& M. T. Kane, unpublished data) that blastocyst growth in the presence of citrate differs to some degree with the batch of charcoal-treated BSA. This could, however, also be due to some batches of BSA being toxic.

Carney \& Foote (1991) report the development of one-cell rabbit embryos to blastocysts in the absence of citrate in a mixture of two media (medium RPMI-1640 and Dulbecco's modified Eagle's medium) with polyvinylalcohol as the only macromolecule. Their results do not conflict with ours, as we are regularly observing the start of blastocyst formation in the absence of citrate, but noting that citrate is essential for continued blastocyst growth. They obtain fewer cells in their citrate-free media $(90-120$ cells/blastocyst) than the mean number (175/blastocyst) we report (Table 1$)$ for embryos cultured in medium without either BSA extract of low $M_{\mathrm{r}}$ or citrate.

It remains to be seen whether the embryotrophic effect of citrate is specific or whether other carboxylic acids or chelating agents will replace citrate. It will also be of interest to see whether citrate promotes the growth of blastocysts of other species.

We thank S. Howell for carrying out the mass spectrometry at the ULIRS Mass Spectrometry facility at the School of Pharmacy, London. This research was supported successively by the Irish National Board for Science and Technology and by the Wellcome Trust.

\section{References}

Abramczuk, J., Solter, D. \& Koprowski, H. (1977) The beneficial effects of EDTA on development of mouse one-cell embryos in chemically defined medium. Devl Biol. 61, 378-383.

Barbehenn, E.K., Wales, R.G. \& Lowry, O.H. (1974) The explanation for the blockade of glycolysis in early mouse embryos. Proc. Natl Acad. Sci., USA 71, $1056-1064$.

Bowman, P. \& McLaren, A. (1970) Cleavage rate of mouse embryos in vivo and in vitro. J. Embryol. exp. Morph. 24, 203-207.

Brackett, B.G. (1981) In vitro culture of the zygote and embryo. In Fertilization and Embryonic Development in Vitro, pp. 61-79. Eds L. Mastroianni, Jr \& J. D. Biggers. Plenum Press, New York.

Brinster, R.L. (1965) Studies on the development of mouse embryos in vitro. II The effect of energy source. J. exp. Zool. 158, 59-68.

Brinster, R.L. (1967) Protein content of the mouse embryo during the first five days of development. $J$. Reprod. Fert. 13, 413-420.

Brinster, R.L. \& Thomson, J.L. (1966) Development of eight-cell mouse embryos in vitro. Exp. Cell Res. 42, 308-315.
Carney, E.W. \& Foote, R.H. (1991) Improved development of rabbit one-cell embryos to the hatching blastocyst stage by culture in a defined, protein-free medium. I. Reprod. Fert. 91, 113-123.

Chatot, C.L., Ziomek, C.A., Bavister, B.D., Lewis, J.L. \& Torres, I. (1989) An improved culture medium supports development of random-bred 1-cell mouse embryos in vitro. J. Reprod. Fert. 86, 679-688.

Cheberek, S. \& Martell, A.E. (1959) Organic Sequestering Agents. John Wiley and Sons, New York.

Cho, M.J., Scieszka, J.F. \& Burton, P.S. (1989) Citric acid as an adjuvant for transepithelial transport. Int. $J$. Pharmaceutics 52, 79-81.

Daniel, J.C., Jr (1964) Early growth of rabbit trophoblast. Am. Nat. 98, 85-97.

Daniel, J.C., Jr (1967) The pattern of utilization of respiratory metabolic intermediates by preimplantation rabbit embryos in vitro. Exp. Cell Res. 47, 619-624.

Fischer, B. (1987) Development retardation in cultured preimplantation rabbit embryos. J. Reprod. Fert. 79, 115--123.

Frye, R.M., Lees, H. \& Rechnitz, G.A. (1974) Magnesium-albumin binding measurements using 
ion-selective membrane electrodes. Clin. Biochem. 7 , 258-270.

Goodridge, A.G. (1972) Regulation of the activity of acetyl coenzyme A carboxylase by palmitoyl coenzyme A and citrate. J. biol. Chem. 247, 6946-6952.

Goodridge, A.G. (1973) Regulation of fatty acid synthesis in isolated hepatocytes. Evidence for a physiological role for long chain fatty acyl coenzyme $\mathrm{A}$ and citrate. $J$. biol. Chem. 248, 4318-4326.

Gray, C.W. (1989) Purification of a low molecular weight embryotrophic factor from bovine serum albumin. Ph.D. thesis, National University of Ireland.

Grayson, K. (1978) An improved method for staining mammalian oocytes. Stain Technol. 53, 115-116.

Ham, R.G. (1963) An improved nutrient solution for diploid Chinese hamster and human cell lines. Expl Cell Res. 29, 515-526.

Kane, M.T. (1983) Variability in different lots of commercial bovine serum albumin affects both cell multiplication and hatching of rabbit blastocysts in culture. J. Reprod. Fert. 69, 555-558.

Kane, M.T. (1985) A low molecular weight extract of bovine serum albumin stimulates rabbit blastocyst cell division and expansion. J. Reprod. Fert. 73, $147-150$.

Kane, M.T. (1987a) In vitro growth of preimplantation rabbit embryos. In The Mammalian Embryo: Regulation of Growth and Differentiation in Vitro, pp. 193-217. Ed. B. D. Bavister. Plenum Press, New York.

Kane, M.T. (1987b) Minimal nutrient requirements for culture of one-cell rabbit embryos. Biol. Reprod. 37, 775-778.

Kane, M.T. (1988) The effects of water soluble vitamins on the expansion of rabbit blastocysts. J. exp. Zool. $245,220-223$.
Kane, M.T. \& Foote, R.H. (1970) Culture of two- and four-cell rabbit embryos to the expanding blastocyst stage in synthetic media. Proc. Soc. exp. Biol. Med. $113,921-925$.

Kane, M.T. \& Headon, D.R. (1980) The role of commercial bovine serum albumin preparations in the culture of one-cell rabbit embryos to blastocysts. $J$. Reprod. Fert. 60, 469-475.

Lowry, O.H. \& Passonneau, J.V. (1972) A Flexible System of Enzymatic Analysis. Academic Press, New York.

Lutwak-Mann, C. (1971) The rabbit blastocyst and its environment: physiological and biochemical aspects. In The Biology of the Blastocyst, pp. 243-260. Ed. R. J. Blandau. University of Chicago Press, Chicago.

Mayr, G.W. (1988) A novel metal-dye detection system permits picomolar-range h.p.l.c. analysis of inositol polyphosphates from non-radioactively labelled cell or tissue specimens. Biochem. J. 254, 585591.

Quinn, P. \& Wales, R.G. (1974) Fixation of carbon dioxide by preimplantation rabbit embryos in vitro. $J$. Reprod. Fert. 36, 29-39.

Steel, R.G.D. \& Torie, J.H. (1960) Principles and Procedures of Statistics. McGraw-Hill Book Company, Inc., New York.

Toyoda, Y., Azuma, S. \& Takeda, S. (1989) Effects of chelating agents on preimplantation development of mouse embryos fertilized in vitro. In Development of Preimplantation Embryos and their Environment, pp. 171-179. Eds K. Yoshinaga \& T. Mori. Alan R. Liss, New York.

Whitten, W.K. \& Biggers, J.D. (1968) Complete development in vitro of the pre-implantation stages of the mouse in a simple chemically defined medium. $J$. Reprod. Fert. 17, 399-401.

Received 15 March 1991 